\title{
Population Scope Code
}

National Cancer Institute

\section{Source}

National Cancer Institute. Population Scope Code. NCI Thesaurus. Code C95343.

A coded value specifying the type of subjects within a population. 